\title{
EUROPEJSKA KARTA SAMORZĄDU LOKALNEGO W ORZECZNICTWIE TRYBUNAEU KONSTYTUCYJNEGO
}

Europejska karta samorządu lokalnego (EKSL, Karta) wywarła istotny wpływ na sytuację samorządu terytorialnego w ustroju państw członkowskich Rady Europy. Charakteryzowana jest jako wzorzec wartości, które kształtują istote „prawdziwego" ${ }^{1}$ samorządu terytorialnego. Stanowi przez to źródło harmonizacji prawodawstwa państw członkowskich w sprawach samorządu terytorialnego i jego jednostek.

Zanim doszło do ratyfikacji Karty², Polska wyznaczyła w rozwiązaniach konstytucyjnych i ustawowych zasady samorządności terytorialnej, a w regulacjach szczegółowych ujęto problemy ustroju gminy, ochronę jej samodzielności prawnej czy sytuację majątkowa (finansowa). Rozwiązania te były zgodne $\mathrm{z}$ treścią odpowiednich regulacji EKSL, co charakteryzowano jako przejaw wprowadzania do prawa polskiego wartości ukształtowanych w Karcie. Polska ratyfikowała Kartę, przyjmujacc za wiążące nie tylko postanowienia wskazane w art. 12 , który wyznacza minimalny zakres związania państwa ratyfikujacego konwencję Rady Europy - uznała wszystkie artykuły Karty za źródło powszechnie obowiąującego prawa.

Stanowisko Polski jest oceniane niezmiennie jako pozytywny przykład reakcji państwa na wyzwania, które wyznacza zaliczenie samorządu terytorialnego do instytucji znamiennych dla systemu ustrojowego. W pewnym okresie aktywności Rady Europy, zwłaszcza w latach dziewięćdziesiątych, przykład Polski inspirował „stare” demokracje europejskie. Odnosiły się bowiem do Karty z rezerwa w zasadzie przez całą dekadę po jej przyjęciu przez Radę w 1985 r. Państwa te podejmowały inicjatywy prowadzące do ratyfikacji EKSL $^{3}$ m.in. w reakcji na przykład Polski.

${ }^{1}$ R. Sowiński, w: Z. Gilowska, L. Kieres, R. Sowiński, Samorzqd terytorialny w Polsce a standardy europejskie, Warszawa 1993, s. 8.

${ }^{2}$ Europejska karta samorządu lokalnego, sporządzona w Strasburgu dnia 15 października 1985 r., Dz. U. 1994, Nr 124, poz. 607; zm.: Dz. U. 2006, Nr 08, poz. 29; sprostowanie: Dz. U. 2006, Nr 154, poz. 1107 - pkt 1, pkt 2, pkt 3; O ratyfikacji EKSL(T) przez Polskę - por. T. Szewc, Dostosowanie prawa polskiego do zasad Europejskiej Karty Samorzqdu Terytorialnego, Bydgoszcz 2005, s. 12 i n.; R. Sowiński, op. cit., s. 9 i n.

${ }^{3}$ Por.: ,4th General Report on Political Monitoring of the Implementation of the European Charter of Local Self-Government", Congress of Local and Regional Authorities of Europe Cham- 
Karta wyznaczyła w Polsce także kierunki prac nad ujęciem innych niż gmina kategorii samorządu lokalnego ${ }^{4}$ oraz odnośnie do sytuacji samorządu regionalnego ${ }^{5}$. Rada Europy, a zwłaszcza jej Kongres Władz Lokalnych i Regionalnych (Congress of Local and Regional Authorities of Europe - CLARE), przygotowała wprawdzie odrębny dokument, który miał kształtować zasady samorządności regionalnej, ale prace nad nim przyniosły pozytywne owoce tylko w wymiarze merytorycznym. Europejska karta samorząu regionalnego (EKSR) została co prawda przyjęta przez Kongres Władz Lokalnych i Regionalnych oraz przez Zgromadzenie Parlamentarne Rady Europy, nie uzyskano jednak konsensusu politycznego w Komitecie Ministrów, co oznacza, że EKSR jest dzisiaj dokumentem o charakterze pewnej deklaracji intencji, przyjętej przez dwie podstawowe instytucje Rady Europy; Karta nie może bez akceptacji Komitetu Ministrów wejść na drogę uznania jej za konwencję Rady Europy, co pozwalałoby na jej przedstawienie państwom członkowskim w celu podpisania oraz ratyfikacji ${ }^{6}$. Dzisiaj wywiera wpływ na regulacje prawa samorządu regionalnego w państwach członkowskich przez dobrowolne i uznaniowe recypowanie jej zasad i rozwiązań szczegółowych na podstawie samodzielnych inicjatyw państw?

Pewnym remedium na obecną patową sytuację w Komitecie Ministrów, która uniemożliwia konwencyjne ujęcie samorządu regionalnego w państwach członkowskich, było sporządzenie "The Reference Framework for Regional Democracy" (RFRD). Dokument ten wprawdzie nie ma charakteru aktu obowiązującego państwa członkowskie Rady Europy, brany jest jednak pod uwagę w procedurach, których celem jest przygotowanie i przyjmowanie przez CLRAE okresowych raportów na temat sytuacji samorządu terytorialnego w państwach członkowskich. Raporty te sa przesyłane do Zgromadzenia Parlamentarnego i Komitetu Ministrów; RFRD został uwzględniony również w 2014 r. przez Komitet Monitorujący CLRAE, który przygotował raport „Local and regional democracy in Poland"8.

ber of Local Authorities, CPL (7) 3, Part I, Part II; L. Kieres, Spojrzenie europejskie, w: M. Lipińska, A. Krasnowolski (red.), Samorzqd terytorialny w państwie i w społeczeństwie, Warszawa 2009, s. 74; A. Szpor, Likwidacja gminy w świetle Europejskiej Karty Samorzqdu Terytorialnego - doświadczenia państw Europy Zachodniej, ,Samorząd Terytorialny” 13, 2003, nr 2-3, s. 116-117.

${ }^{4}$ Por. o rozumieniu gospodarki komunalnej: H. Izdebski, Samorzad terytorialny. Podstawy ustroju i działalności, Warszawa 2009, s. 148; o braku możliwości zastosowania EKSL do samorządu województwa pisze T. Szewc, op. cit., s. 43 i n.; idem, Charakterystyka Europejskiej Karty Samorzqdu Terytorialnego, „Samorząd Terytorialny” 13, 2003, nr 1-2, s. 136; inaczej: M. Perkowski, Gtówne podstawy prawnomiędzynarodowe aktywności zagranicznej samorzadu terytorialnego $w$ Europie, „Białostockie Studia Prawnicze” 2012, nr 12, s. 15.

${ }^{5}$ Art. 13 Karty pozwala na stosowanie jej postanowień do wszystkich kategorii społeczności lokalnych, co w interpretacjach tego postanowienia uznawane jest za możliwość, ale nie zobowiązanie stosowania EKSL także do społeczności regionalnych

${ }^{6}$ H. Izdebski, Samorzqd terytorialny. Podstawy ustroju i działalności, Warszawa 2014, s. 109.

${ }^{7}$ W. Gonet, Zakres swobody w zawieraniu umów przez jednostki samorzqdu terytorialnego, Warszawa 2011, s. 20-21 - pisze o EKSR jako „wskazówce, jaki powinien być ustrój samorządu regionalnego"; błędnie o związaniu państw EKSR pisze: M. Szypliński, Organizacja, zadania i funkcjonowanie samorzqdu terytorialnego, Toruń 2011, s. 137 i n.

${ }^{8} \mathrm{CG} / \mathrm{MON}(27) 3-$ pkt 3.4 . 
Istotnym źródłem informacji dla instytucji usytuowanych w strukturze Rady Europy jest orzecznictwo sądowe, zwłaszcza przy formułowaniu analiz o sytuacji samorządu terytorialnego. Szczególnie pozytywne wrażenie wywołuje uznanie przez państwa członkowskie kognicji sądów konstytucyjnych do formułowania ocen o zgodności przepisów prawa w sprawach samorządu terytorialnego z aktami (wzorcami) konstytucyjnymi. Rada Europy wykazuje się bowiem wrażliwością na przypadki naruszania zasad odnoszonych do samorządu terytorialnego, które ujęto w treści dokumentów tej organizacji międzynarodowej i recypowano do konstytucyjnego porządku prawnego. Rada konsekwentnie promuje stanowisko o doniosłej roli orzecznictwa konstytucyjnego jako formy promowania i ochrony w prawie wewnętrznym standardów, które rządzą prawdziwą samorządnością terytorialną.

Polski Trybunał Konstytucyjny jest uznawany przez Radę Europy za instytucję pełniącą ważną rolę w postępowaniach, których celem jest ocena zgodności aktów prawa wewnętrznego z EKSL. Wrażenie to gruntuje zwłaszcza przywoływanie w orzecznictwie trybunalskim postanowień Karty. Sam fakt uznawania przez Trybunał Konstytucyjny postanowień Karty za wiążące źródło prawa, które idzie przed regulacjami ustawowymi, oraz wywodzenie z treści postanowień EKSL wzorców kontroli aktów ustawowych czy podustawowych sa podkreślane w dokumentach Rady Europy jako przykład reakcji właściwej dla demokratycznego państwa prawnego.

Opracowanie jest poświęcone omówieniu stanowiska Trybunału Konstytucyjnego wobec treści regulacyjnych, ujętych w poszczególnych postanowieniach Karty. Trybunał nie tylko je przywołuje w swoich orzeczeniach. Wyznacza w swoich judykatach także kierunki interpretacji postanowień Karty czy też wywodzi z tych postanowień treści, którym nadaje własne i swoiste znaczenie. Celem opracowania jest więc ustalenie przede wszystkim znaczenia, jakie Trybunał przyznaje EKSL przy wyróżnianiu wzorców konstytucyjnych i kontroli zgodności z nimi aktów normatywnych, które kształtują sytuację polskiego samorządu terytorialnego.

\section{II}

Trybunał Konstytucyjny pozostawał poza sporem o konstytucyjność postępowania ratyfikacyjnego EKSL. Pominięcie w tym postępowaniu Sejmu i nieuzyskanie jego zgody na ratyfikację nie stanowiło dla Trybunału problemu, który należało rozważać w ocenach Karty jako źródła polskiego porząadku prawnego. Trybunał przyjął, że Karta jest aktem prawnie obowiązujacym i może być przywoływana jako wzorzec, ,„[...] z którym porównywany jest zaskarżony przepis ustawowy w istniejącym stanie konstytucyjnym"9. Pogląd ten promuja przede wszystkim orzeczenia trybunalskie w sprawach samorządu terytorialnego, wydawane pod rządami Konstytucji z 1997 r. Trybunał nie weryfikował

\footnotetext{
${ }^{9}$ Wyrok TK z 26 lutego 2003 r., K 30/02, OTK ZU 2003, nr 2A, poz. 16; oczywiście Trybunał przyjmował odmienne stanowisko do czasu ratyfikacji Karty, a także pod rządami Małej Konstytucji z 1992 r. - por: E. Tegler, Glosa do orzeczenia Trybunatu Konstytucyjnego z 25.X.1995 r. K 4/95, „Samorząd Terytorialny” 6, 1996, nr 7-8, s. 162.
} 
postępowania ratyfikacyjnego Karty; została uznana przez Polskę, co potwierdza złożenie odpowiednich i prawnie wiążących oświadczeń w Radzie Europy $^{10}$. Karta jest więc właściwym źródłem standardów adresowanych do ustawodawcy krajowego ${ }^{11}$, kiedy stanowi wewnętrzne regulacje prawne. Pogląd ten wyrażono wprost w niektórych orzeczeniach TK, kiedy Trybunał wskazuje na ujętą w przepisach Karty ${ }^{12}$ regulację i uznaje ją za wiążąca dla polskiego ustrojodawcy; ocena zgodności regulacji konstytucyjnych z EKSL „[...] oznacza realizację standardu określonego w [...] EKSL [...]" przez Konstytucję $e^{13}$.

Trybunał idzie jednak dalej w określaniu relacji między EKSL a polskim prawem wewnętrznym. Przyjmuje, że przepisy Karty należy brać pod uwagę także przy interpretacji prawa. Uznanie Karty za źródło wzorców (odniesień) przy weryfikacji aktów normatywnych polskich władz publicznych (ustawy, akty podustawowe $)^{14}$ inspiruje do formułowania oceny, że orzecznictwo trybunalskie afirmatywnie odnosi się do normatywnego i wiążącego charakteru regulacji przyjętych w EKSL ${ }^{15}$. Trybunał, określając Kartę jako źródło standardów regulacyjnych, wskazuje zarazem na ogólny charakter rozwiąań przyjętych w EKSL. Wyznaczaja one przede wszystkim zasady kierunkowe co do usytuowania samorządu terytorialnego w ustroju państwa oraz co do ich organizacji wewnętrznej ${ }^{16}$. Powyższe stanowisko jest promowane w orzecznictwie trybunalskim także przy okazji rozważań i formułowania szczegółowych ocen na temat zgodności tych instytucji prawa polskiego, które w istotny sposób charakteryzuja prawny obraz polskiego samorządu terytorialnego np. wysłowionych w regulacjach prawa wyborczego, zakorzenionych $\mathrm{w}$,standardach demokratycznych dotyczących wyborów do organów stanowiących jednostek samorządu terytorialnego" ${ }^{17}$.

\section{III}

Poczynione wyżej ustalenia o relacjach między Konstytucją a EKSL służą Trybunałowi Konstytucyjnemu pomocą w procesach wyróżniania wzorców, przyjmowanych w kontroli aktów prawa samorządu terytorialnego oraz rekonstrukcji treści tych wzorców. W postępowaniach kontrolnych dochodzi zwykle do konfrontacji (zestawienia) przez TK Konstytucji z Karta, co jednak nie oznacza potrzeby ich jednoczesnego uwzględniania. Trybunał Konstytucyjny wyróżnia bowiem sytuacje, kiedy ujęcia regulacyjne ustanowione w prawie polskim

${ }^{10}$ Wyrok TK z 18 lipca 2006 r., U 5/04, OTK ZU 2006, nr 7A, poz. 80.

11 Wyrok TK z 20 marca 2007 r., K 35/05, OTK ZU 2007, nr 3A, poz. 28.

12 Np. co do art. 5 EKSL - wyrok TK z 26 lutego 2003 r., K 30/02, OTK ZU 2003, nr 2A, poz. 16.

13 Wyrok TK z 31 stycznia 2013 r., K 14/11, OTK ZU 2013, nr 1A, poz. 7.

${ }_{14}$ Postanowienie TK z 5 listopada 2009 r., U 9/07, OTK ZU 2009, nr 110A, poz. 152.

15 Z. Bukowski, Źródła prawa w zakresie samorzqdu terytorialnego, w: Z. Bukowski, T. Jędrzejewski, P. Raczka, Ustrój samorzadu terytorialnego, Toruń 2013, s. 102.

${ }^{16}$ Wyrok TK z 18 lipca 2006 r., U 5/04.

17 Wyrok TK z 3 listopada 2006 r., K 31/06, OTK ZU 2006, nr 10A, poz. 147; też: T. Szewc: Uwagi $w$ sprawie ratyfikacji Europejskiej Karty Samorzqdu Terytorialnego, „Państwo i Prawo” 57,2002 , z. 9 , s. 56 . 
(Konstytucja i ustawy) pozostają w zgodzie z rozwiązaniami Karty - w prawie polskim znajdujemy „odpowiedniki”"18 rozwiąań europejskich. Stan taki jest wynikiem swego rodzaju prostego i bezpośredniego przejęcia przez prawo polskie rozwiązań EKSL, co zwalnia ze szczegółowego analizowania postanowień Karty w procesie oceny zaskarżonych regulacji prawa polskiego. Trybunał zwykle w takich okolicznościach tylko przywołuje odpowiednie przepisy EKSL lub nawet o nich nie wzmiankuje, ujęte w nich bowiem treści regulacyjne zostały uwzględnione w aktach prawa polskiego, które stanowią bezpośrednie źródło kształtowania wzorców kontroli zaskarżonych regulacji normatywnych. Trzeba też zaznaczyć, że w wielu przypadkach sami skarżący (wnioskodawcy) nie wskazują postanowienia EKSL jako źródło wzorca, właściwego dla kontroli zgodności zaskarżonego aktu prawnego (normy prawnej).

Trybunał znajduje usprawiedliwienia przywoływania EKSL, jeżeli Konstytucja lub ustawy nie wystarczają do weryfikacji skarżonej regulacji. Ważne znaczenie można w takich okolicznościach przyznawać ocenie trybunalskiej, że „[...] postanowienia [...] EKSL uzupełniają [Konstytucję] w sferze rozwoju instytucji demokracji lokalnej w zakresie spraw zastrzeżonych do kompetencji organów władz ogólnopaństwowych [...]"19.

Trybunał dopuszcza bezpośrednią właściwość regulacyjną EKSL, jeżeli ustalenie wzorca kontroli na podstawie Konstytucji nie jest możliwe, bowiem ustrojodawca zaniechał ujęcia w jej treści wartości, przyjętych w Karcie. Oznacza to „[...] brak regulacji konstytucyjnej [...]"20. Trybunał dopuszcza wówczas przyznanie EKSL charakteru „[...] adekwatnego źródła prawa”, które jest właściwe dla ukształtowania wzorca kontroli aktu normatywnego. Warunkiem uznania Karty za taki adekwatny akt jest wywiedzenie z jej treści jednoznacznego obowiązku „[...] ustanowienia odpowiednich regulacji ustawowych, które urzeczywistnią zagwarantowane w niej uprawnienia” dla samorządu terytorialnego ${ }^{21}$.

Istnieje jednak granica swobody reakcji, którą Trybunał narzuca także sobie przy stwierdzaniu braku zgodności prawa polskiego z postanowieniami wiążących Polskę umów międzynarodowych. Granice „ingerencji” regulacji prawnomiędzynarodowych w wewnętrzny porządek prawny wyznaczaja podstawowe dla polskiego systemu konstytucyjnego wartości, które stanowia o jego tożsamości i są nieusuwalne ${ }^{22}$. Wydaje się, że obowiąująca wersja EKSL nie zawiera rozwiązań, które pozostawałyby w opozycji do fundamentalnych praw i wolności konstytucyjnych.

Wreszcie TK dopuszcza swego rodzaju pomocnicze przywoływanie przepisów EKSL, jeżeli odwołanie się do nich pomaga w ustaleniu wzorca kontroli zaskarżonych przepisów (aktów prawa polskiego). Odpowiedzialnością Trybu-

18 Wyrok TK z 18 lipca 2006 r., U 5/04.

19 Wyrok TK z 23 października 2012 r., U 1/10, OTK ZU 2012, nr 9A, poz. 108 - co do art. 4 ust. 2 EKSL; wyrok TK z 26 lutego 2003 r., K 30/02, OTK ZU 2003, nr 2A, poz. 16; inaczej rzecz się ma w sytuacjach odstępstw istotnych lub nieistotnych prawa polskiego od regulacji EKSL - por. o tym: T. Szewc, Formy realizacji prawa do samorzadu w Europejskiej Karcie Samorzadu Terytorialnego i w prawie polskim, „Państwo i Prawo” 59, 2004, z. 7, s. 58.

${ }^{20}$ Wyrok TK z 31 stycznia 2013 r., K 14/11.

21 Ibidem.

${ }^{22}$ Wyrok TK z 11 maja 2005 r., K 18/04, OTK ZU 2005, nr 5A, poz. 49. 
nału jest wówczas właściwe wyważenie rangi wartości, wywiedzionych z Konstytucji oraz prawa europejskiego i nadanie im odpowiedniego znaczenia przy rekonstrukcji wzorca kontroli.

Trybunał nie akceptuje natomiast inicjatyw podejmowanych w celu uznania Karty za źródło wzorców w ocenach założeń prawodawczych („celowość zamierzenia" ${ }^{23}$ ) czy też przy weryfikowaniu regulacji prawnych przyjmowanych przez władze publiczne, kiedy regulacje te mieszczą się w kategoriach właściwych dla rządzenia ${ }^{24}$. Nie znajduje tym samym uzasadnienia konstytucyjnego stanowisko, które do sfery faktów przenosi przedmiot kontroli zgodności działań władz publicznych, jeżeli skutki tych działań przenikają do sytuacji jednostek samorządu terytorialnego. To, co TK określa „sferą faktów”, zawiera w sobie treści właściwe dla polityki stanowienia czy stosowania prawa (rzadzenie), nie jest natomiast stanowieniem prawa czy jego stosowaniem.

Podobny pogląd został odniesiony w orzecznictwie trybunalskim do życia politycznego w samorządzie terytorialnym. Trybunał wprawdzie pozytywnie weryfikuje stanowisko ustawodawcy, w którym wyraża akceptację dla udziału czynnika politycznego - zwłaszcza wpływu partii politycznych na organizację pracy samorządu terytorialnego. Wpływ aktywności o charakterze politycznym może jednak - zdaniem Trybunału - prowadzić do zjawisk ocenianych jako naganne (patologiczne ${ }^{25}$ ), czego szczególnym wyrazem jest zwłaszcza partyjnictwo jako przejaw niskiej kultury politycznej elit czy nawet społeczeństwa i jego wspólnot obywatelskich. Zachowania takie, jeżeli nie prowadzą do naruszenia praw i wolności konstytucyjnych, powinny pozostawać poza sferą zainteresowania (kognicja) Trybunału. Nie jest on bowiem sądem sumień ludzkich, nawet jeżeli wyzwalają one zachowania lub postawy budzące sprzeciw, czy wręcz odrazę.

Zachowania możemy charakteryzować jako naganne, co ma miejsce przy uwzględnianiu w ich ocenach wartości uznawanych za kanony przyzwoitości czy też odpowiadajacych przymiotom właściwym dla ludzi honoru. Niekiedy takie złe zachowania sa jednak tolerowane, a nawet akceptowane przez społeczeństwo. Nie wszystkie z tych postaw podlegają jednak weryfikacji z uwzględnieniem treści nadanych przez normy prawne. Ustawodawca może zarazem zakreślać nieprzekraczalne granice dla takich zachowań, uwzględniając wartości konstytucyjne.

\section{IV}

Europejska karta samorządu lokalnego wyznacza podstawowe cechy znamienne wspólnoty samorządowej (preambuła). Rozwiązania Karty nawiąują do podejścia naturalistycznego przy wskazywaniu na źródła samorządności terytorialnej oraz pierwiastki, które wyznaczają jej tożsamośćch

${ }^{23}$ Wyrok TK z 23 listopada 2006 r., K 31/06, OTK ZU 2006, nr 10A, poz. 147.

${ }^{24}$ Wyrok TK z 28 kwietnia 2009 r., K 37/06, OTK ZU 2009, nr 4A, poz. 47.

${ }^{25}$ Wyrok TK z 3 listopada 2006 r., K 31/06, OTK ZU 2006, nr 10A, poz. 147.

${ }^{26}$ Por. o koncepcji naturalistycznoprawnej samorządu terytorialnego: I. Skrzydło-Niżnik, Model ustroju samorzadu terytorialnego w Polsce na tle zagadnień ustrojowego prawa administracyjnego, Kraków 2007, s. 290 i n. 
Prawodawca europejski (Rada Europy) wywodzi ten obiektywny charakter samorządności terytorialnej także z doświadczeń państw, które swój ustrój budowały z uwzględnieniem samorządności jako podstawowego prawa obywatela ${ }^{27}$.

Naturalistyczne spojrzenie na istotę samorządu terytorialnego prowadzi do uznania niezbywalności prawa do samorządu terytorialnego. „Prawo do samorządu istnieje niezależnie od rozstrzygnięć ustawodawcy. Ustawodawca określa jedynie formy realizacji tego prawa w granicach określonych przy założeniu istnienia gminy jako podstawowej jednostki samorządu terytorialnego" ${ }^{28}$.

$\mathrm{W}$ orzecznictwie TK i ujawnionych w jego treści ocenach znajdujemy również odniesienia do tych postanowień EKSL, które wskazują na istotę samorządności terytorialnej (art. 3 EKSL). Trybunał wywodzi z Karty rozumienie samorządu terytorialnego jako wspólnoty. Samorzą terytorialny to społeczność mieszkańców o cechach charakteryzujących ową społeczność jako wspólnotę ${ }^{29}$. Społeczność samorządowa uzyskuje przymiot wspólnoty lokalnej przede wszystkim przez wyróżnienie w prawie (Konstytucja, ustawy) jej pewnych cech znamiennych.

EKSL wyznacza w swoich regulacjach dyrektywę, która stanowi o kształtowaniu miejsca samorządu terytorialnego w ustroju państwa z uwzględnieniem zasady kompetencji powierzonych. Karta adresuje bowiem do ustawodawstw krajowych wymóg powierzenia odpowiedzialności za sprawy publiczne temu organowi, który znajduje się najbliżej obywateli (art. 4 ust. 3 Karty) ${ }^{30}$. Przywołany przepis ujmuje zasadę decentralizacji jako dyrektywę legislacyjna, która winna rządzić stanowiskiem prawodawcy wewnętrznego przy sytuowaniu samorządu terytorialnego w ustroju państwa. Wskazanie w EKSL na decentralizację wyraża zarazem stanowisko prawodawcy europejskiego w kwestii odpowiedzialności, która odnosi do prawodawcy krajowego za przyjmowanie rozwiązań sprzyjających usytuowaniu samorządu terytorialnego w ustroju państwa jako zdecentralizowanej formy życia publicznego.

Decentralizacja samorządowa oznacza więc stan rzeczywistej, ujętej w treści norm prawnych, sytuacji samorządu terytorialnego oraz jego jednostek. Sytuację tę wyznaczają wartości szczególne, które Trybunał uznaje za przejaw faktycznej decentralizacji: szeroka autonomia kompetencyjna, samodzielność co do wyboru form wykonywania uprawnień oraz środków niezbędnych do realizacji zadań. Trybunał podkreśla niezbędność wyróżnionych wyżej wartości w usytuowaniu samorządu terytorialnego w państwie ${ }^{31}$; samorządność terytorialna nie może być rozumiana w kategoriach właściwych dla sztafażu czy idei, wyrażonych wyłącznie w ornamentyce słownej.

Interpretacja zasady decentralizacji prowadzi Trybunał do wywodzenia z jej treści zasad szczególnych (cząstkowych), które wyznaczają miejsce samo-

\footnotetext{
27 Por. B. Dolnicki, Samorzqd terytorialny, Warszawa 2012, s. 20.

${ }^{28}$ Wyrok TK z 18 lutego 2003 r., K 24/02, OTK ZU 2003, nr 2A, poz. 11.

${ }^{29}$ Wyrok TK z 4 listopada 2003 r., K 1/03, OTK ZU 2003, nr 8A, poz. 85; wyrok TK z 4 listopada 2003 r., K 1/03, OTK ZU 2003, nr 8A, poz. 85; wyrok TK z 26 lutego 2003 r., K 30/02.

${ }^{30}$ Wyrok TK z 18 lipca 2006 r., U 5/04.

31 Wyrok TK z 4 listopada 2003 r., K 1/03.
} 
rządu w zdecentralizowanym ustroju państwa (zasada pomocniczości, zasada autonomii komunalnej, zasada proporcjonalności) ${ }^{32}$. Tak wyróżnione zasady wskazuja na kierunki działania ustawodawcy przy kształtowaniu treści norm prawnych. Ustawodawca powinien zarazem kierować się w takiej aktywności pewnym pragmatyzmem, który Trybunał wiąże z „zakresem i charakterem zadania oraz wymogami efektywności gospodarczej”33 czy też przywołuje „wzgląd na prawo do dobrej administracji”34.

Trybunał wywodzi z Karty oraz rozwiąań konstytucyjnych nie tylko przesłanki wspierajace decentralizację. Wyróżnia również wartości, które limituja decentralizację zadań i funkcji państwa do samorządu terytorialnego. Inspiracją do poszukiwań takich klauzul limitacyjnych na płaszczyźnie regulacji konstytucyjnych jest zwłaszcza stanowisko ujęte w art. 4 ust. 2 EKSL. Karta wskazuje na prawo wewnętrzne jako właściwe do określenia zakresu swobody działania samorządu terytorialnego w każdej sprawie, która nie została wyłączona z kompetencji samorządu lub nie wchodzi w zakres kompetencji innych podmiotów władzy publicznej.

Trybunał odnajduje w art. 4 ust. 2 Karty inspiracje do uznania właściwości i odpowiedzialności prawodawcy wewnętrznego do określania zadań (kompetencji) jednostek samorządu terytorialnego ${ }^{35}$. Określanie kompetencji samorządu terytorialnego może zarazem prowadzić do wyłączania z gestii samorządu terytorialnego pewnych spraw, ujmowanych w kategoriach dobra wspólnego „i przekazywania ich innym organom władzy”36. Wyróżnia warunki owego wyłączania (,w zgodzie z Konstytucja, w drodze ustawy, przy poszanowaniu zasady racjonalności”) ${ }^{37}$, a ich przestrzeganie uznaje za oblig wiążący prawodawcę. „Decentralizacja nie może być rozumiana w sposób mechaniczny, w oderwaniu od kontekstu interpretacyjnego stanowiącego konsekwencję całokształtu zasad i wartości konstytucyjnych składających się na ustrój państwa" ${ }^{38}$.

Państwo jest „dobrem wspólnym wszystkich obywateli”39, co obliguje ustawodawcę do rozumienia decentralizacji w sposób przyjazny dla poszanowania owego „dobra wspólnego”. Szkodliwe zarazem jest przyjmowanie rozwiąań usprawiedliwianych interesem państwa, jeżeli prowadzą do fasadowego ujęcia samorządności terytorialnej. Prawdziwa samorządność terytorialna mieści się bowiem także w treści „dobra wspólnego” i je wspiera.

\footnotetext{
${ }^{32}$ Wyrok TK z 18 lutego 2003 r., K 24/02. Por. A. Piekara, Podstawy doktrynalne odrodzonego samorzadu terytorialnego w Polsce, w: E. Jasiuk (red.), XX lat odrodzonego samorzadu terytorialnego $w$ Polsce, Radom 2011, s. 17.

${ }^{33}$ Wyrok TK z 18 lipca 2006 r., U 5/04.

${ }^{34}$ Wyrok TK z 18 lutego 2003 r., K 24/02.

${ }_{35}$ Wyrok TK z 24 maja 2004 r., K 40/02, OTK ZU 2004, nr 5A, poz. 38.

${ }^{36}$ Wyrok TK z 18 lipca 2006 r., U 5/04.

37 Wyrok TK z 15 kwietnia 2002 r., K 23/01, OTK ZU 2002, nr 2A, poz. 19.

38 Wyrok TK z 18 lutego 2003 r., K 24/02.

39 Ibidem.
} 
Cechą znamienną samorządu terytorialnego jest związanie wspólnoty samorządowej z określonym terytorium, na którym zamieszkują jej członkowie ${ }^{40}$. Ustawodawca polski łączy samorządność terytorialną z zasadniczym podziałem terytorialnym państwa. Trybunał wskazuje, że pojęcie zasadniczego podziału terytorialnego ma charakter autonomiczny ${ }^{41} \mathrm{w}$ tym znaczeniu, że jest związane z samorządem i jego kategoriami (jednostki samorządu lokalnego i regionalnego) oraz podziałem na jednostki samorządowe w ramach poszczególnych kategorii samorządu terytorialnego ${ }^{42}$. Trybunał Konstytucyjny wskazuje zarazem na związanie w EKSL (preambuła) terytorium samorządowego z pojęciem autonomii społeczności lokalnych. Prowadzi to Trybunał do wyróżnienia autonomii w ujęciu terytorialnym - autonomii terytorialnej ${ }^{43}$.

Poszanowanie samorządności odniesionej przez Kartę do terytorium jednostki samorządowej obliguje ustawodawcę do ustanowienia gwarancji ochrony wspólnoty przed arbitralnymi rozstrzygnięciami przy wyznaczaniu granic terytorialnych wspólnoty i ich zmian. Trybunał wprawdzie wiąże te rozstrzygnięcia z uprawnieniami państwa, ich realizacja wymaga jednak wskazania na przesłanki usprawiedliwiające zmiany, które powinny mieścić się w kategorii dobra wspólnego (interes ponadlokalny) ${ }^{44}$. Szczególną gwarancją ochrony wspólnoty samorządowej przed rozstrzygnięciami arbitralnymi jest ustanowienie obowiązku konsultowania zmiany granic z zainteresowanymi wspólnotami samorządowymi (art. 5 EKSL) ${ }^{45}$. W stanowisku powyższym wyraża się zarazem pogląd TK o ustalonej w EKSL istocie samorządu terytorialnego, która to kategoria ustrojowa ma charakter nieprzenoszalny w tym znaczeniu, że za samorząd terytorialny nie mogą być uznawane jego organy ${ }^{46}$.

\section{VI}

Trybunał wielokrotnie rozważał sposób ujęcia w Karcie relacji między państwem a samorządem terytorialnym, analizując pojęcie autonomii. Przede wszystkim zwracał uwage, że w Karcie mowa jest o szerokiej autonomii, co nie jest tożsame $\mathrm{z}$ autonomią pełna ${ }^{47}$. Takie spojrzenie na autonomię inspiro-

${ }^{40}$ P. Lisowski, Relacje strukturalne $w$ polskim samorzqdzie terytorialnym, Wrocław 2013, s. 196 i n.

${ }^{41}$ Wyrok TK z 28 kwietnia 2009 r., K 37/06, OTK ZU 2009, nr 5A, poz. 75.

${ }^{42}$ Wyrok TK z 10 grudnia 2002 r., K 27/02, OTK ZU 2002, nr 7A, poz. 92.

43 Wyrok TK z 4 maja 2004 r., K 440/02.

${ }_{44}$ Wyrok TK z 4 listopada 2003 r., K 1/03.

${ }^{45}$ M. Kruszewska-Gagoś, Podmiotowość prawna gminy w Polsce w świetle Europejskiej Karty Samorzqdu Lokalnego, „Roczniki Nauk Prawnych” 16, 2006, z. 2, s. 375.

${ }^{46}$ Wyrok TK z 26 lutego 2003 r., K 30/02, OTK ZU 2003, nr 2A, poz. 16; wyrok TK z 26 lutego 2003 r., K 30/02, OTK ZU 2003, nr 2A, poz. 16; T. Szewc, Uwagi w sprawie tłumaczenia Europejskiej Karty Samorzadu Terytorialnego, „Samorząd Terytorialny” 12, 2002, nr 11, s. 11-12.

${ }_{47}$ Wyrok TK z 18 września 2006 r., K 27/05, OTK ZU 2006, nr 8A, poz. 105; Wyrok TK z 4 maja 2004 r., K 440/02; wyrok TK z 18 września 2006 r., K 27/05, OTK ZU 2006, nr 8A, poz. 105. 
wało Trybunał do poszukiwania przedmiotu odniesienia autonomii - ustalenie płaszczyzny, którą wyznaczają zachowania samorządu terytorialnego jako przejaw jego szerokiej autonomii. Odnajduje ów przedmiot odniesienia szerokiej autonomii samorządu terytorialnego w kompetencjach, które wiąże przede wszystkim z zadaniami oraz ich wykonywaniem (autonomia wykonawcza), a także ze środkami umożliwiającymi realizację zadań ${ }^{48}$.

$\mathrm{O}$ zadaniach samorządowych oraz o zadaniach poszczególnych kategorii samorządu terytorialnego przesądza wola ustawodawcy. Trybunał formułuje ten pogląd w wyniku analizy art. 4 ust. 2 Karty stanowiącego o sprawach, które nie są wyłaczone z kompetencji społeczności lokalnych ${ }^{49}$. Nie znajduje zarazem usprawiedliwienia przyznania jednostkom samorządowym chronionej prawnie swobody do określania zadań ${ }^{50}$. Myślenie trybunalskie prowadzi ostatecznie do wniosku o prawie samorządów terytorialnych do działania „w każdej sprawie, która nie jest wyłączona z ich kompetencji lub nie wchodzi w zakres kompetencji innych organów władzy"51, co wypełnia znamiona właściwe dla zasady pomocniczości ${ }^{52}$. Trybunał przyjmuje zarazem, że prawo do określania zadań (kompetencji) mieści w sobie również ograniczanie kompetencji samorządu terytorialnego ${ }^{53}$ czy też uznawanie kompetencji władz ponadlokalnych do rozwiązywania problemów publicznych, jeżeli ich rozwiązywanie przez lokalne jednostki samorządowe nie jest możliwe (zasada subsydiarności) ${ }^{54}$.

Uzasadnienie ujęcia autonomii wykonawczej (,granic[e] swobody działania społeczności lokalnych" ${ }^{\text {5 }}$ ) Trybunał znajduje w art. 16 ust. 2 Konstytucji, który stanowi o wykonywaniu przez samorząd terytorialny zadań (,to, co mieści się w zakresie właściwości samorządu terytorialnego" $\left.{ }^{56}\right)$. Trybunał Konstytucyjny, charakteryzując autonomię kompetencyjną jako prawo do działania, zarazem wywodzi z niej swobodę jednostek samorządowych do działania we własnym imieniu i na własną odpowiedzialność oraz rozważa jej treść w kategoriach właściwych samodzielności prawnej i samodzielności prawem chronionej ${ }^{57}$.

Tak ujęta autonomia samorządowa, przypisana - zdaniem TK - do wykonywania prawem określonych zadań, przejawia się w stosunkach publicznoprawnych. Trybunał znajduje ją również w sytuacji jednostki samorządowej jako podmiotu stosunków prywatnoprawnych ${ }^{58}$. W analizach aspektów

\footnotetext{
${ }^{48}$ Wyrok TK z 18 września 2006 r., K 27/05; wyrok TK z 4 maja 2004 r., K 440/02.

${ }^{49}$ Por.: L. Kieres, Analiza zgodności polskiego prawa samorzadu terytorialnego $z$ Europejska Karta Samorzadu Terytorialnego, „Samorząd Terytorialny” 8, 1998, nr 9, s. 24 i n.

${ }^{50}$ Por. J. Jagoda, Sadowa ochrona samodzielności jednostek samorzqdu terytorialnego, Warszawa 2011, s. 71-73.

${ }^{51}$ Wyrok TK z 4 maja 2004 r., K 40/02.

${ }^{52}$ Por. K. Strzyczkowski, Prawo gospodarcze publiczne, Warszawa 2011, s. 93-96.

${ }^{53}$ Ibidem.

${ }^{54}$ Wyrok TK z 18 lutego 2003 r., K 24/02.

${ }^{55}$ Wyrok TK z 18 września 2006 r., K 27/05.

${ }^{56}$ Wyrok TK z 28 kwietnia 2009 r., K 37/06; też: M. Waniewska-Bobin, Europejskie modele samorzadu terytorialnego, Lublin 2013, s. 19.

${ }^{57}$ Wyrok TK z 18 lutego 2003 r., K 24/02, OTK ZU 2003, nr 2A, poz. 11; wyrok TK z 18 lutego 2003 r., K 24/02; wyrok TK z 20 marca 2007 r., K 35/05; OTK ZU 2007, nr 3A, poz. 28.

${ }^{58}$ Wyrok TK z 26 września 2006 r., K 1/06, OTK ZU 2006, nr 8A, poz. 110.
} 
sytuacji prywatnoprawnej jednostek samorządowych Trybunał wskazuje na osobowość prawną i prawo własności jako szczególne elementy konstrukcyjne samodzielności samorządowej ${ }^{59}$.

\section{VII}

Trybunał Konstytucyjny stanowczo i zarazem konsekwentnie wskazuje na samodzielność, w wymiarze wyżej określonym, jako istotową cechę samorządności terytorialnej ${ }^{60}$. Podnosi tak rozumianą samodzielność do rangi zasady szczególnej, co wynika nie tylko z prawnego przyznania samorządowi terytorialnemu samodzielności, ale także z prawnej jej ochrony ${ }^{61}$. Pogląd ten wyraża dyrektywa, adresowana do ustawodawcy, zakazu znoszenia owej samodzielności w całości lub co do przesądzającej o jego istocie części ${ }^{62}$, a zarzut naruszenia tego zakazu może być weryfikowany w postępowaniach przed TK. Formalna gwarancja ochrony samodzielności w tych dwóch wymiarach (pozbawienie w całości lub części samodzielności) podlega kontroli sądowej, co Trybunał przywołuje w swoim orzecznictwie ${ }^{63}$. Przywoływanie to nie zawsze jednak prowadzi Trybunał do stanowiska o celowości ochrony samodzielności w sposób bezwzględny.

Ostrożność, widoczna w podejściu trybunalskim przy wyznaczaniu istoty i granic samodzielności, wynika z konsekwentnie promowanego w trybunalskich judykatach założenia o braku możliwości „absolutyzowania” samodzielności samorządu terytorialnego ${ }^{64}$. Konstytucja wprawdzie pozwala na kojarzenie samodzielności z wyróżnioną w EKSL autonomią samorządu terytorialnego, trybunalskie rozumienie autonomii jest jednak zakorzenione w konstytucyjnym usytuowaniu samorządu w ustroju państwa. Status ten należy weryfikować z uwzględnieniem interesu państwa jako dobra wspólnego, gdyż „Samorząd nie istnieje sam dla siebie”65.

W sposób szczególny charakter państwa jako dobra wspólnego wyraża zasada jego jednolitości; samodzielność samorządu terytorialnego jest realizowana w państwie jednolitym ${ }^{66}$ (konstytucyjna zasada jednolitości państwa ${ }^{67}$ ). Tym samym samorząd terytorialny jest wprawdzie kategoria obiektywna i niezależną od woli prawodawcy, jego istnienie jest jednak kształtowane przez poszanowanie owego dobra wspólnego. Oznacza to konieczność uwzględniania w analizach, które prowadzą do wyznaczenia samodzielności samorządu tery-

${ }^{59}$ Wyrok TK z 29 września 2009 r., K 32/08, OTK ZU 2009, nr 9A, poz. 08.

${ }^{60}$ Por. J. Jagoda, op. cit., s. 27-56.

61 Wyrok TK z 27 września 1994 r., W. 10/93, OTK 1994, cz. II, poz. 46.

62 Wyrok TK z 4 maja 1998 r., K 38/97, OTK ZU 1998, nr 3, poz. 31.

${ }^{63}$ Wyrok TK z 29 października 2009 r., K 32/08.

${ }^{64}$ Wyrok TK z 18 lutego 2003 r., K 24/02; wyrok TK z 28 kwietnia 2009 r., K 37/06; wyrok TK z 13 marca 2013 r., K 25/10; wyrok TK z 31 stycznia 2013 r., K 14/11, OTK ZU 2013, nr 3A, poz. 27.

${ }^{65}$ Wyrok TK z 18 lutego 2003 r., K 24/02.

${ }^{66}$ Wyrok TK z 4 maja 1998 r., K 38/97.

${ }^{67}$ Wyrok TK z 28 kwietnia 2009 r., K 37/06. 
torialnego w wybranych wymiarach prawnych, różnych wartości (praw i wolności konstytucyjnych) oraz zasad ustrojowych, ich zestawiania i poszukiwania między nimi wzajemnych odniesień. Samorząd i jego samodzielność podlegaja wprawdzie ochronie, rozumienie tej ochrony jednak nie może prowadzić do znoszenia prawa ustawodawcy do regulowania stosunków w państwie w celu poszanowania i promowania wartości konstytucyjnych, które w pewnych sytuacjach, konfrontowane z zasadą ochrony samodzielności samorządu terytorialnego idą przed nią. Tak wyrażona swoboda regulacyjna ustawodawcy nie jest jednak tożsama w skutkach $\mathrm{z}$ autonomią prawodawczą wobec samorządu terytorialnego. Trybunał wskazuje na ograniczenia formalne i materialne $\mathrm{e}^{68}$, które wyznaczają pola aktywności regulacyjnej (treść swobody regulacyjnej).

Aspekt formalny swobody odniesiono do ustawowej formy regulacyjnej ${ }^{69}$, która pozwala na uskutecznianie zamiaru ograniczenia samodzielności samorządu terytorialnego. Trybunał przede wszystkim uznaje za zgodne z art. 3 ust. 1 i 2 EKSL określanie sytuacji samorządu terytorialnego, jeżeli przyjęto formę ustawy dla unormowania tej sytuacji. Stanowienie w formie ustawy o sprawach samorządu terytorialnego nie może jednak prowadzić do naruszania prawa samorządu terytorialnego „do kierowania i zarządzania zasadniczą częścią spraw publicznych”, wyróżnionego w Karcie (art. 3 ust. 1) - o czym dalej. Trybunał zaznacza zarazem, że to prawo samorządu terytorialnego nie ma charakteru absolutnego. Wprawdzie jest ono realizowane „przez rady lub zgromadzenia" (art. 3 ust. 2 EKSL), ale w granicach przysługujacej im swobody regulacyjnej, którą określa prawodawca, kierując się stanowiskiem ustrojodawcy przy określaniu granic samorządności ${ }^{70}$. Ograniczenie ustawowe samodzielności samorządu terytorialnego może prowadzić do utraty „mocy obowiąujaccej przez akty normatywne wydane przez te jednostki na podstawie ustaw [...]"71. Stan taki powstaje zarówno przez uchylanie, jak i zmiany ustaw obowiązujacych.

W wyrazie materialnym samodzielność samorządu terytorialnego podlega ochronie przez wymóg przywoływania wartości konstytucyjnych, jako przesłanek usprawiedliwiających ingerencję w samodzielność samorządu terytorialnego. W znaczeniu negatywnym pogląd trybunalski należy przede wszystkim interpretować jako wywodzenie z Konstytucji zakazu limitowania samodzielności samorządowej w sferze zadań (modyfikowanie zakresu zadań), jeżeli w argumentacji uzasadniającej ingerencję w samodzielność samorządu terytorialnego pominięto odniesienia do wartości konstytucyjnych, które wymagaja ochrony. Trybunał znajduje te wartości przede wszystkim w art. 31 ust. 3 Konstytucji (bezpieczeństwo lub porządek publiczny, ochrona środowiska, zdrowie i moralność publiczna, wolności i prawa innych osób) ${ }^{72}$ i ujmuje ich znaczenie w kategoriach doniosłości (ingerencja konieczna ${ }^{73}$ ).

\footnotetext{
68 Wyrok TK z 20 marca 2007 r., K 35/05.

69 Wyrok TK z 28 kwietnia 2009 r., K 37/06.

${ }^{70}$ Wyrok TK z 29 września 2009 r., K 32/08.

71 Wyrok TK z 12 marca 2007 r., K 54/05, OTK ZU 2007, nr 3A, poz. 25.

72 Wyrok TK z 26 września 2006 r., K 1/06, OTK ZU 2006, nr 8A, poz. 110.

${ }^{73}$ Wyrok TK z 21 grudnia 1998 r., U 20/97, OTK ZU 1998, nr 7, poz. 119.
} 
Wyróżnienie przez Trybunał Konstytucyjny przesłanek usprawiedliwiających ingerencję w samodzielność samorządu terytorialnego i uznanie ich za doniosłe stanowi zarazem dla Trybunału inspirację do sformułowania pewnej dyrektywy kierunkowej, która adresuje do ustawodawcy. Trybunał wskazuje bowiem na istotę doniosłości - pokazuje, co ja charakteryzuje i w czym owa doniosłość się wyraża. Ustawodawca, szukając usprawiedliwień ingerencji w samodzielność samorządu terytorialnego, winien przyjmować dla nich miarę odpowiadająca randze wartości wyróżnionych w art. 31 ust. 3. Wkraczanie $\mathrm{w}$ sferę zastrzeżonej prawnie samodzielności samorządu terytorialnego nie może być usprawiedliwiane potrzebą ochrony wartości bądź dążeniami do osiagnięcia celów przyjętych przez władzę ingerującą w zachowania samorzą$\mathrm{du}^{74}$, jeżeli za takim zamiarem stoją względy bagatelne.

Przywoływanie wartości chronionych powinno zarazem pozostawać w zgodzie z realnymi, a nie hipotetycznymi przesłankami usprawiedliwiajacymi reakcję ustawodawcy. Ustawodawca nie może przyznawać sobie autonomii w analizach doniosłości i wyborze owych usprawiedliwień. Tak ujęta dyrektywa usprawiedliwiająca ingerencję kojarzona jest $\mathrm{z}$ inną zasada - ograniczonej swobody regulacyjnej prawodawcy ${ }^{75}$. Trybunał zwraca na nią uwagę $\mathrm{w}$ swoich judykatach, kiedy wskazuje, że ochrona nie może prowadzić do nadmiernych ograniczeń samodzielności, co ujmuje także jako zakaz wykraczania „poza granice niezbędne dla ochrony interesu publicznego"76 czy też pozytywnie - „[...] regulacja ta jest niezbędna (konieczna) dla ochrony interesu publicznego" ${ }^{77}$. $\mathrm{W}$ tak formułowanych stanowiskach trybunalskich w istocie sa zakotwiczone zasady: celowości oraz proporcjonalności ingerencji prawodawczej w sferę samodzielności samorządu terytorialnego - jego jednostek ${ }^{78}$.

Względy ochrony interesu publicznego prowadzić mogą do stanowienia regulacji czy innych działań wywołujących skutki niezgodne z interesem jednostek samorządu terytorialnego, którego treścią jest chronione konstytucyjnie prawo do samodzielności. Trybunał widzi usprawiedliwienia konstytucyjne takich naruszeń, posiłkując się w swojej argumentacji postanowieniami EKSL ${ }^{79}$. Trybunał zwraca jednocześnie uwagę, że usprawiedliwiana względami ochrony interesu publicznego ingerencja winna być miarkowana przez ocenę jej skutków dla społeczności samorządowych. W treści zasady proporcjonalności Trybunał odnajduje zakaz ingerencji ponad niezbędną potrzebę, co wiąże z zakazem ingerencji nadmiernej ${ }^{80}$. Środki przyjmowane w ustawach dla ochrony interesu publicznego kosztem interesu wspólnot samorządowych muszą tym samym być współmierne ${ }^{81}$ do znaczenia interesu chronionego.

${ }^{74}$ Wyrok TK z 20 marca 2007 r., K 35/05; wyrok TK z 18 września 2006 r., K 27/05.

75 Wyrok TK z 12 marca 2007 r., K 54/05, OTK ZU 2007, nr 3A, poz. 25.

76 Wyrok TK z 20 marca 2007 r., K 35/05.

77 Wyrok TK z 4 maja 1998 r., K 38/97.

78 Wyrok TK z 15 kwietnia 2002 r., K 23/01, OTK ZU 2002, nr 2A, poz. 19; wyrok TK z 4 maja 1998 r., K 38/97; wyrok TK z 4 maja 2004 r., K 40/02.

79 Wyrok TK z 4 listopada 2003 r., K 1/03.

80 Wyrok TK z 20 marca 2007 r., K 35/05; wyrok TK z 18 lutego 2003 r., K 24/02.

${ }^{81}$ Wyrok TK z 15 kwietnia 2002 r., K 23/01. 
Naruszenie określonej wyżej relacji między potrzebą ochrony interesu publicznego przez ingerencję oraz środkami i skutkami owej ingerencji $\mathrm{w}$ istocie prowadzi do odstapienia od konstytucyjnego wymogu zachowania proporcjonalności $\mathrm{w}$ działaniach ingerujących $\mathrm{w}$ samodzielność samorzadu terytorialnego. Przejawy takiego nagannego zachowania ustawodawcy w procesie legislacyjnym to arbitralność, oderwanie od rzeczywistości gospodarczej ${ }^{82}$, odstapienie od racjonalnego uzasadnienia ingerencji czy jej nadmiernośćc ${ }^{83}$.

Każdy przypadek ingerencji charakteryzuje się cechami swoistymi, determinowanymi charakterem i ranga interesu publicznego ${ }^{84}$. Przede wszystkim nie może prowadzić do wzruszania „wewnętrznych stosunków polityczno-terytorialnych" ${ }^{85}$, czy też do osłabiania zdolności wykonywania przez nią zadań. Wewnętrzne stosunki polityczno-terytorialne oraz zdolność do wykonywania zadań publicznych stanowią bowiem o tożsamości wspólnoty samorządowej i kształtuja treść tej wspólnoty ${ }^{86}$.

Trybunał nie chce zarazem stawiać się w roli instytucji rozsądzającej spory co do treści rozważanych regulacji ustawowych, które sa projektowane z intencją wkroczenia w sferę samodzielności samorządu terytorialnego lub zawierają upoważnienia do takiej ingerencji. Widzi możliwość reakcji tylko w okolicznościach jednoznacznie wskazujących na skutki obowiązywania unormowań, kwalifikowane jako nadmierna ingerencja regulacji prawnej w aktywność samorządowa. O celowości przyjęcia projektowanych rozwiązań należy bowiem rozważać przede wszystkim z uwzględnieniem wartości kojarzonych z zasadami właściwymi racjonalności i kulturze prawnej ${ }^{87}$. Wartości te powinny kształtować postawy osób lub instytucji, które uczestniczą w procedurach stanowienia prawa lub maja na nie wpływ.

\section{VIII}

Wszystko to, co powiedziano wyżej na temat samodzielności samorządu terytorialnego $\mathrm{w}$ świetle postanowień EKSL oraz regulacji prawa polskiego poddanych interpretacji w orzecznictwie TK, prowadzi do pytania o gwarancje prawne samodzielności. Europejska karta samorządu terytorialnego zwraca uwagę na podstawowe znaczenie, jakie dla ochrony samodzielności samorządu terytorialnego ma zasada ochrony sądowej samodzielności (art. 11). Trybunał wskazuje na to postanowienie ${ }^{88}$, inspirowany zarzutami formułowanymi

${ }^{82}$ Ibidem.

${ }^{83}$ Wyrok TK z 18 lutego 2003 r., K 24/02.

${ }^{84}$ Por. M. Szydło, Wolność działalności gospodarczej jako prawo podstawowe, Bydgoszcz-Wrocław 2011, s. 189-198.

${ }^{85}$ Wyrok TK z 4 listopada 2003 r., K 1/03.

${ }^{86}$ Postanowienie TK z 5 września 2009 r., U 9/07.

87 Wyrok TK z 18 lutego 2003 r., K 24/02.

${ }^{88}$ Wyrok TK z 8 kwietnia 2009 r., K 37/06. 
we wnioskach, które w treści (skarg, pytań prawnych) przywołują stanowisko Rady Europy ukształtowane w art. 11 EKSL.

Podstawowe znaczenie dla trybunalskiego ujęcia zasady sądowej ochrony samodzielności samorządu terytorialnego ma art. 165 ust. 2 Konstytucji. Trybunał interpretuje stanowisko ustrojodawcy, wysłowione w tym postanowieniu, przez uwzględnienie innych regulacji konstytucyjnych, które kształtuja miejsce samorządu terytorialnego w systemie ustrojowym państwa. Wskazując na zasadę sądowej ochrony, przywołuje zwłaszcza zasadę jednolitości państwa. Trybunał przyznaje tej zasadzie wyróżniające znaczenie w interpretacji statusu samorządu terytorialnego i istoty jego samodzielności; samodzielność samorządu nie ma charakteru absolutnego ${ }^{89}$.

Odrzucenie przez Trybunał Konstytucyjny możliwości ujmowania sytuacji samorządu terytorialnego i jego jednostek w kategoriach niezależności wobec państwa prowadzi zarazem do uznania prawa ustrojodawcy i ustawodawcy do kształtowania istoty i granic samodzielności. Realizowane jest ono przede wszystkim przez wyznaczanie zadań samorządu terytorialnego. Zadania te wyznaczają pole działalności samorządu terytorialnego oraz przedmiotowy wymiar jego samodzielności. Samorządowi przysługuje tym samym prawo do ochrony sądowej przed działaniami innych władz publicznych, które nakładaja obowiązki podejmowania przez jednostki samorządowe aktywności poza sfera zadań ustawowo przypisanych do poszczególnych kategorii samorządowych.

Trybunał uznaje samodzielność za wartość zmienną; nie wiąże z jej istotą pierwiastka trwałości i nienaruszalności (niezbywalności). Pogląd ten potwierdza związek ochrony sądowej z samodzielnościa, ujmowaną w aspekcie przedmiotowym; ochronie podlega prawo samorządu terytorialnego do działalności w celu realizacji zadań, wyznaczonych przez ustawy ${ }^{90}$; inne władze publiczne moga przejmować zadania związane z jednostkami samorządowymi tylko w wyniku usprawiedliwionej interwencji ustawodawcy. Przesłanki usprawiedliwionej interwencji ustawodawcy w sferę zadań samorządu terytorialnego nie sa przez niego dowolnie wybierane. Wybór ten podlega kontroli TK, który kieruje się w ocenach wyłożonymi wcześniej zasadami, odnoszonymi do pozycji samorządu terytorialnego w ustroju państwa. Trybunał limituje zarazem ochronę samodzielności samorządu terytorialnego przez związanie jej z prawem do działania, którego granice wyznaczają ustalone zadania, wyznaczone przez konstytucyjne i ustawowe regulacje prawne. „Sądowej ochronie może podlegać to, co mieści się w zakresie właściwości samorządu terytorialnego ukształtowanym w Konstytucji i ustawach”.

Pogląd, podobny do wyżej przedstawionego, Trybunał kojarzy z samodzielnością funkcjonalną (sposób - organizacja wykonywania zadań), którą także zalicza do przedmiotu ochrony sądowej. W tym jednak wymiarze ochrony sa-

89 Ibidem.

${ }_{90}$ Por. K. Kokocińska, Samodzielność jednostek samorzqdu terytorialnego w organizowaniu usług publicznych, w: M. Jabłoński, K. Kiczka (red.), Współdziałanie podmiotów publicznych i prywatnych w sferze gospodarki komunalnej, „Przegląd Prawa i Administracji” 98, 2014, s. 79-89; por. też K. Horubski, Udział gminy w spółce prowadzacej działalność w sferze sportu profesjonalnego, w: L. Kieres (red.), Nowe problemy badawcze w teorii publicznego prawa gospodarczego z uwzględnieniem samorzadu terytorialnego, Wrocław 2010, s. 107-110. 
modzielności samorządowej Trybunał kieruje uwagę nie tylko na kategorię dobra wspólnego (społecznego, państwa), lecz także na konieczność uwzględniania interesów wspólnot samorządowych. Obowiązkiem ustawodawcy jest jednak zestawianie tych interesów z interesem publicznym, ich ważenie i wybór odpowiedniego rozwiązania. „Granica respektowania odrębności interesów wspólnot samorządowych pozostaje dobro wspólne i interes publiczny podlegajace ochronie zgodnie z konstytucyjnymi zasadami ustroju państwa"91. Tak rozumiany związek między interesem społeczności samorządowych a dobrem wspólnym ma swoje konsekwencje - zdaniem Trybunału - w rozumieniu sądowej ochrony samodzielności.

Związanie samodzielności samorządowej, której zakres podlega kształtowaniu przez ustawodawcę, z ochrona sądowa, pozwala - zdaniem TK - na uznanie „szerszej swobody ustawodawcy co do wyboru sposobów jej urzeczywistnienia"92. Trybunał przyjmuje, że prawo do ochrony sądowej powinno być realizowane zarówno w postępowaniu cywilnym oraz w postępowaniu sądowoadministracyjnym. Ustawodawca korzysta ze swobody przez wyróżnienie sąów (ich kognicji) właściwych do sprawowania wymiaru sprawiedliwości w sprawach samodzielności samorządu terytorialnego oraz co do układu procedury sądowej czy środków zaskarżania ${ }^{93}$.

\section{IX}

Samorządność terytorialna jest szczególną instytucją w ustroju państwa, a jej tożsamość współkształtuje łączenie funkcji sprawowania władzy publicznej (państwa) z wykonywaniem zadań w imieniu i na rzecz społeczności samorządowej ${ }^{94}$. Europejska karta samorządu lokalnego, ujmując sytuację wspólnot lokalnych, ustala również ich sytuację wobec innych kategorii władz publicznych, które wykonują funkcje państwa (delegowane funkcje państwa) na terytorium jednostki samorządowej. Stanowi w art. 5 o instytucji konsultacji oraz określa referendum jako kwalifikowaną formę konsultacji.

Trybunał zwraca uwage na dwa aspekty ujęcia regulacyjnego przyjętego w treści art. 5 EKSL. Wskazano w nim przede wszystkim na obowiązek przeprowadzenia konsultacji w sytuacjach wyróżnionych w Karcie, co dotyczy zwłaszcza zmiany granic wspólnot lokalnych. Komentowany przepis nie pozbawia zarazem ustawodawcy wewnętrznego uprawnienia do uznania referendum za właściwą formę konsultacji w innych sprawach rozstrzyganych przez władze publiczne ${ }^{95}$.

91 Wyrok TK z 28 kwietnia 2009 r., K 37/06.

92 Wyrok TK z 29 października 2009 r., K 32/08.

93 Por. J. Jagoda, op. cit., s. 127-132.

${ }_{94}$ Por. J. Korczak, Konstytucyjne podstawy struktury $i$ funkcji samorzadu terytorialnego, w: System prawa administracyjnego, t. 2: Konstytucyjne podstawy funkcjonowania administracji publicznej, Warszawa 2012, s. 177-200.

95 Postanowienie TK z 5 września 2009 r., U 9/07. 
Konsultacje (referendum) są instytucją czysto fasadową, jeżeli dyrektywa, wyłożona w art. 5 EKSL, podlega interpretacji wyłącznie z uwzględnieniem kategorii formalnych przez wywodzenie z niej przede wszystkim obowiązków uregulowania przesłanek, zasad i procedury organizowania konsultacji, ale bez ustalenia znaczenia prawnego ich wyników. Pozostanie przez prawodawcę wewnętrznego tylko przy uregulowaniu przesłanek, uprawniajaccych czy nawet obligujacych władze rozstrzygajace w sprawach samorządu terytorialnego (grup mieszkańców) do konsultowania (organizowania referendum) z adresatami (mieszkańcami) projektowanych rozstrzygnięć oraz uregulowanie procedur owego konsultowania, ale bez ustanowienia obligu uwzględnienia lub co najmniej rozważenia wyników konsultacji, mogłoby prowadzić do uznawania przez zainteresowaną społeczność samorządową rozstrzygnięć władz centralnych za arbitralne ${ }^{96}$.

Konsekwencją opisanego wyżej formalistycznego podejścia do współdziałania władz publicznych ze wspólnotami samorządowymi może być osłabienie lub nawet zanik więzi łączących członków społeczności lokalnych, czy też nawet wywołanie poczucia zniechęcenia do idei samorządności terytorialnej. Tymczasem podkreślana w orzecznictwie TK doniosłość znaczenia konsultacji władz centralnych z samorządem terytorialnym ma prowadzić do rozumienia samorządności jako rzeczywistego, a nie fasadowego przejawu udziału obywateli w rządzeniu.

Trybunał zdaje sobie sprawę ze wskazanego wyżej niebezpieczeństwa. Przywołuje bowiem w swoich orzeczeniach nie tylko art. 5 EKSL, ale także weryfikuje jego treść regulacyjną przez jej odniesienie do art. 170 Konstytucji, który stanowi o udziale bezpośrednim wspólnot samorządowych w sprawach, załatwianych przez nie lub też w sprawach, które są rozstrzygane przez inne władze publiczne. Zestawienie art. 5 EKSL z art. 170 Konstytucji wskazuje, że „Nasze państwo stwarza zatem większe gwarancje dla lokalnej demokracji bezpośredniej niż te, które wynikaja z podpisania i ratyfikowania EKSL" Trybunał uznaje zarazem, że przyjmowanie przez władze publiczne projektów rozstrzygnięć (ich treści) w sprawach samorządowych „nie może podlegać sądowej kontroli"98; kontroli podlegają bowiem co do zasady akty woli władz publicznych, które wywołują skutki rozważane w kategoriach właściwych dla interesu samorządowego.

Trybunał wywodzi przy tym z art. 5 EKSL i akceptuje dyrektywę, adresowaną do ustawodawcy wewnętrznego, wiązania w regulacjach przedmiotu i procedury konsultacji z „zainteresowaną społecznościa”. Społecznością zainteresowaną sa mieszkańcy jednostki osadniczej, którą projektowane rozwiązania „bezpośrednio dotkna”" ${ }^{9}$. W przywołanym sformułowaniu kryje się wymóg dążenia do osiagnięcia najpełniejszej reprezentatywności wyniku konsultacji. Najpełniej ową reprezentatywność charakteryzuje przede wszystkim referendum. Prowadzi bowiem do realizacji postulatu, wywodzonego przez TK

\footnotetext{
96 Wyrok TK z 4 listopada 2003 r., K 1/03.

97 Wyrok TK z 26 lutego 2003 r., K 30/02.

98 Wyrok TK z 8 czerwca 2009 r., K 35/07, OTK ZU 2009, nr 6A, poz. 90.

99 Ibidem.
} 
z EKSL, uregulowania konsultacji w prawie wewnętrznym w sposób, który zapewni wynikom konsultacji szczególną doniosłośćc ${ }^{100}$ czy „rangę i doniosłość polityczną wypowiedzi” ${ }^{101}$. W tych poglądach Trybunału widać, że istota reprezentatywności w rozumieniu trybunalskim ogarnia kumulatywnie nie tylko aspekty proceduralne. Trybunał widzi w konsultacjach także wartości o charakterze materialnym, kiedy władza rozstrzygajacca o sprawach społeczności lokalnej zwraca się do zainteresowanych wspólnot o wyrażenie stanowiska w celu jego poważnego rozważenia, co może prowadzić do jego akceptacji przez władzę rozstrzygająca.

\section{X}

Inną wartościa, którą Trybunał Konstytucyjny uwzględnia w analizach ujęć konstytucyjnych samodzielności samorządu terytorialnego, jest zdolność wykonywania zadań, ujmowana w aspekcie finansowych gwarancji ochrony tej zdolności. Trybunał przywołuje art. 9 EKSL, w którym wysłowiono zasadę zapewnienia zdolności finansowej jednostek samorządu terytorialnego do działania. Regulacja ta pozostaje w treściowych związkach z konstytucyjnym ujęciem zasady samodzielności finansowej samorządu terytorialnego (art. 167 ust. 1 Konstytucji) ${ }^{102}$ oraz wskazaniem na jej gwarancje (art. 167 ust. 2 i 3) (03 $^{103}$.

W orzecznictwie trybunalskim w sprawach finansów samorządu terytorialnego widać konsekwencję w promowaniu tezy o wiązaniu interesu jednostek samorządowych z interesem państwa, ujmowanego w kategoriach właściwych dla dobra wspólnego, które Trybunał wiąże z całym społeczeństwem. Samorząd terytorialny odpowiada nie tylko za realizację zadań ważnych dla wspólnot samorządowych (zadania własne). Ich realizacja jest również istotna dla państwa; w interesie państwa leży stworzenie odpowiednich warunków, wspomagających realizację zadań przez jednostki samorządu terytorialnego, co odnosi się nie tylko do zadań zleconych, ale także do zadań własnych. Dlatego - co do zasady - jednostkom samorządu terytorialnego należy się udział w dochodach publicznych. Udział ten powinien być adekwatny do „przypadających im zadań” ${ }^{104}$; środki powinny wystarczać na finansowanie realizacji zadań samorządowych.

Adekwatność udziału samorządu terytorialnego w dochodach państwa jest wartością podstawową w sytuacji prawnej samorządu terytorialnego; powinna stabilizować tę sytuację, co wymaga przyjęcia systemu gwarancji zapewnia-

100 Wyrok TK z 4 listopada 2003 r., K 1/03.

101 Wyrok TK z 26 lutego 2003 r., K 30/02.

102 Wyrok TK z 18 września 2006 r., K 27/05; por. też: M. Orłowska-Bednarz, Społeczność lokalna jako podstawa ustroju demokratycznego w świetle Europejskiej Karty Samorzadu Terytorialnego, w: R. Paradowski (red.), Unia Europejska a społeczeństwo obywatelskie, Poznań 2005 , s. 161 .

103 Wyrok TK z 21 grudnia 1998 r., U 20/97, OTK ZU 1998, nr 7, poz. 119.

104 Wyrok TK z 31 maja 2005 r., K 27/04, OTK ZU 2005, nr 5A, poz. 54. 
jących poszanowanie owej adekwatności ${ }^{105}$. Taką funkcją gwarancyjną (wywiedziona z art. 9 ust. 2 EKSL) jest odniesienie do państwa obowiązu zapewnienia jednostkom samorządowym środków finansowych, które pozwalają na realizację zadań ${ }^{106}$. Zarzut o nieadekwatności środków finansowych, które znajdują się w dyspozycji samorządu terytorialnego i są przeznaczone na wykonywanie zadań, powinien charakteryzować nieadekwatność jako istotna ${ }^{107}$ w tym znaczeniu, że środki finansowe nie pozwolą co najmniej na właściwe wykonanie zadań samorządowych.

Państwo jest zarazem uprawnione do wyboru właściwych (odpowiednich) źródeł finansowania kosztów działalności, podejmowanej i wykonywanej przez jednostki samorządu terytorialnego. Państwo zapewnia te środki przede wszystkim przez przyznanie jednostkom samorządowym „własnych zasobów finansowych" (art. 9 ust. 1 EKSL) ${ }^{108}$.

Realizacja postulatu prawodawcy strasburskiego zapewnienia samorządowi terytorialnemu środków, adekwatnych do potrzeb finansowania zadań, podlega ocenie z uwzględnieniem ,całokształtu dochodów jednostki samorządu terytorialnego"109. Dla oceny o naruszeniu art. 9 ust. 1 i 2 EKSL oraz art. 167 Konstytucji nie wystarcza ustalenie nieadekwatności jednego źródła dochodu (np. dotacji) do finansowania realizacji wskazanego zadania. Więcej - jednostka samorządu terytorialnego winna przede wszystkim sama szacować swoje zdolności finansowania zadań publicznych i - odpowiednio do wyników takich szacunków - to do niej należy prowadzenie racjonalnej polityki finansowej, co TK odnosi zwłaszcza do polityki podatkowej ${ }^{110}$. Trybunał Konstytucyjny wiąże tym samym adekwatność w znaczeniu wyżej opisanym z aktywnością o „charakterze samodzielnym i kreatywnym”111. Samodzielność oznacza uprawnienie do wyboru - w granicach prawa - sposobu realizacji zadań oraz źródeł ich finansowania ${ }^{112}$ (zasada swobody kształtowania wydatków) ${ }^{113}$. Realizacja tak określonego postulatu wymaga - zdaniem Trybunału - spełnienia istotnego warunku. Tym warunkiem jest przyjęcie przez ustawodawcę zróżnicowanych i elastycznych systemów finansowych, „na jakich [...] opierają się zasoby pozostające do dyspozycji społeczności lokalnych [...] tak aby mogły w miarę możliwości odpowiadać rzeczywistym zmianom zachodzącym w poziomie kosztów związanych z wykonywaniem uprawnień"114.

105 Por.: J. Kowalik, Finanse gminne w Polsce w świetle standardów Europejskiej Karty Samorzqdu Lokalnego, w: J. Jaskiernia (red.), Wpływ standardów międzynarodowych na rozwój demokracji $i$ ochrone praw człowieka. Materiaty konferencyjne (Warszawa, 22-23.04.2012 r.), t. 2, Warszawa 2013, s. 120 i n.

106 Wyrok TK z 19 grudnia 2007 r., K 52/05, OTK ZU 2007, nr 11A, poz. 159.

107 Wyrok TK z 16 lipca 2013 r., K 13/10, OTK ZU 2013, nr 6A, poz. 77.

108 Wyrok TK z 21 grudnia 1998 r., U 20/97.

109 Wyrok TK z 20 marca 2007 r., K 35/05.

110 Wyrok TK z 31 stycznia 2013 r., K 14/11.

111 Wyrok TK z 20 marca 2007 r., K 35/05, OTK ZU 2007, nr 3A, poz. 28.

112 Wyrok TK z 28 czerwca 2001 r., U 8/00, OTK ZU 2001, nr 5, poz. 123.

113 Wyrok TK z 18 września 2006 r., K 27/05, OTK ZU 2006, nr 8A, poz. 105.

114 Wyrok TK z 21 grudnia 1998 r., U 20/97; wyrok TK z 31 stycznia 2013 r., K 14/11, OTK ZU 2013, nr 1A, poz. 7; W. Miemiec, Europejska Karta Samorzadu Terytorialnego jako zespót gwarancji samodzielności finansowej gmin - wybrane zagadnienia teoretycznoprawne, w: S. Dolata (red. i wstęp), Funkcjonowanie samorzadu terytorialnego - diagnozy i perspektywy, Opole 1997, s. 216. 
Trybunał wyprowadza wreszcie z zasady adekwatności wymóg stabilizowania źródeł dochodów samorządu terytorialnego, co jednak - zdaniem TK - nie oznacza utrwalania ich niezmienności. Zmiany w tych systemach są dopuszczalne, lub nawet w pewnych okolicznościach - konieczne, np. ze względu na sytuację finansowa państwa ${ }^{115}$.

Trybunał wywodzi uprawnienie ustawodawcy do korekt w systemach finansowania zadań wszystkich trzech kategorii polskiego samorządu terytorialnego - zarówno z Konstytucji (art. 167 ust. 1, 2 i 4), jak i z art. 9 ust. 1, 2 EKSL $^{116}$. Uzasadnieniem zmian powinny być jednak przesłanki (kryteria ${ }^{117}$ ) obiektywne, co wyklucza uznaniowość ustawodawcy w wykonywaniu funkcji regulacyjnej przy normowaniu źródeł dochodów samorządu terytorialnego. Zmiany te nie mogą być drastyczne ${ }^{118}$.

Nie narusza zasady adekwatności przyjmowanie regulacji, które przejściowo wprowadzaja niekorzystne zmiany $\mathrm{w}$ gospodarce finansowej samorząu terytorialnego. Temporalny charakter takich zmian nie obliguje ustawodawcy - zdaniem TK - do modyfikacji układu zadań samorządu terytorialnego czy też do przyjmowania „zmian w podziale dochodów publicznych” ${ }^{119}$. Trybunał tym samym nie widzi naruszenia art. 167 ust. 4 Konstytucji i art. 9 ust. 1 i 4 EKSL $^{120} \mathrm{w}$ takiej przejściowo niekorzystnej sytuacji finansowej samorządu terytorialnego.

\section{XI}

Powyższe rozważania pozwalają przede wszystkim na stwierdzenie przywoływania przez Trybunał Konstytucyjny Europejskiej karty samorządu lokalnego jako źródła wzorców kontroli aktów normatywnych, które stanowia o sytuacji samorząu terytorialnego. Trybunał nie nadaje jednak znaczenia przesądzającego postanowieniom EKSL w analizach tej sytuacji. Odniesienia w orzeczeniach Trybunału do Karty zwykle mają na celu uzyskanie argumentów, które wspierają stanowisko trybunalskie, wywodzone z postanowień Konstytucji. Trybunał dopuszcza zarazem możliwość uznawania EKSL za samodzielne źródło wzorców kontroli prawa polskiego, co może zwłaszcza wystapić $\mathrm{w}$ sytuacji zaniechania przez polskiego ustrojodawcę przyjęcia w Konstytucji rozwiązań wymaganych przez Kartę.

Trybunał dokonuje w swoim orzecznictwie interpretacji postanowień Karty. Interpretacja to prowadzi do wydobywania z tych postanowień treści, które Trybunał charakteryzuje na tle odpowiednich postanowień Konstytucji. Innymi słowy - spośród możliwych kierunków interpretacji regulacji przyjętych

\footnotetext{
115 Wyrok TK z 26 września 2013 r., K 22/12, OTK ZU 2013, nr 7A, poz. 95.

116 Wyrok TK z 31 stycznia 2013 r., K 14/11.

117 Ibidem.

118 Wyrok TK z 25 lipca 2006 r., K 30/04, OTK ZU 2006, nr 7A, poz. 86.

119 Wyrok TK z 21 grudnia 1998 r., U 20/97.

120 Wyrok TK z 21 grudnia 1998 r., U 20/97; wyrok TK z 16 lipca 2013 r., K 13/10.
} 
w Karcie wybiera taki, który prowadzi przede wszystkim do sankcjonowania stanowiska polskiego ustrojodawcy. Pogląd ten w sposób wyraźny aktualizują zwłaszcza orzeczenia, w których Trybunał wywodzi o uznaniu w Konstytucji samorządu terytorialnego za naturalny i obiektywny element ustroju państwa. Wskazuje jednak zarazem, że to wola ustrojodawcy i ustawodawcy określa sytuację samorządu w państwie. Polski samorząd terytorialny w aktualnej rzeczywistości konstytucyjnej spełnia warunki przyjęte w EKSL dla samorządności terytorialnej. Zgodności prawa polskiego z Kartą nie podważa odrzucenie przez Konstytucję koncepcji samorządności terytorialnej wyrażonej przez samodzielność o cechach znamiennych dla autonomii, którą charakteryzuje prawo do przeciwstawiania przez jednostkę samorządową własnych interesów państwu jako dobru wspólnemu obywateli.

prof. dr hab. Leon Kieres

Uniwersytet Wroctawski,

Sędzia Trybunatu Konstytucyjnego

\title{
EUROPEAN CHARTER OF LOCAL SELF-GOVERNMENT IN JUDICIAL DECISIONS OF THE CONSTITUTIONAL TRIBUNAL
}

\begin{abstract}
Summary
When it comes to deciding upon a review model of normative acts regulating the situation of self-government, the Constitutional Tribunal regards the Constitution as the main source of such a model. However, the Constitutional Tribunal also invokes provisions of the European Charter of Local Self-Government as the source of a review model of normative acts that regulate the situation of self-government. The latter, however, is done only to support the rationale of judgments based on the Constitution, thus in the process of a Constitutional Tribunal review of normative acts, the European Charter is an ancillary document. At the same time, it is permissible to exclude the provisions of the European Charter when it is impossible to determine a review model due to the fact that an issue regulated in the European Charter has not been addressed in the Constitution. The significance of this, however, may only become apparent in the future, if certain amendments to the Constitution have been made, resulting in a constitutional omission.
\end{abstract}


